ISSN 1978 - 3000

\title{
Pengaruh Suplementasi Ekstrak Daun Katuk (Sauropus androgynus) dalam Ransum Berbasis Lumpur Sawit Fermentasi Terhadap Performans Ayam Ras Petelur
}

\author{
Katuk Leave Extract (Sauropus androgynus ) in Fermented Palm Oil Sludge-Based Diet \\ on Layers Performance
}

\section{Ria Puspitasari, Desia Kaharuddin, Urip Santoso, Yosi Fenita}

Jurusan Peternakan, Fakultas Pertanian, Universitas Bengkulu

Jalan W.R. Supratman Kandang Limun Bengkulu 38371A

Email: ria.puspita2010@yahoo.com

\begin{abstract}
The purpose of this research was to evaluate the effect of katuk leave extract supplemented (Sauropus androgynus) in fermented palm oil sludge-based diet on performance of layers. This study used 50 layers aged 16 month of production period. Layers were distributed to 5 treatments groups as follows: P0 (control), P1 (control $+15 \%$ fermented palm oil sludge (FPOS), P2 (control $+15 \%$ FPOS $+6 \mathrm{~g} / \mathrm{kg}$ Sauropus androgynus extract (SAE), P3 (control + $15 \%$ FPOS $+9 \mathrm{~g} / \mathrm{kg} \mathrm{SAE}$ ) and P4 (control + $15 \%$ FPOS $+12 \mathrm{~g} / \mathrm{kg}$ SAE). The results showed that SAE suplemented in fermented palm oil sludge-based diet did not significantly affect to feed consumption $(\mathrm{P}>0.05)$ but significantly affected egg production $(\mathrm{P}<0.01)$ and feed conversion $(\mathrm{P}<0.05)$. The best level of SAE suplementation is $6 \mathrm{~g} / \mathrm{kg}$ fed diet. In conclusion, SAE supplementation at level of $6 \mathrm{~g} / \mathrm{kg}$ diet in fermented palm oil sludge-based diet did not increase fed consumption but increased egg production and reduced feed conversion ratio
\end{abstract}

Keywords: Fermented Palm Oil Sludge, Sauropus androgynus Leave Extract, Layer Performance

\begin{abstract}
ABSTRAK
Penelitian ini bertujuan untuk untuk mengevaluasi pengaruh suplementasi ekstrak daun katuk (Sauropus androgynus) dalam ransum berbasis lumpur sawit fermentasi terhadap performans ayam ras petelur. Penelitian ini menggunakan 50 ekor ayam petelur fase produksi 16 bulan. Ayam petelur tersebut terbagi dalam 5 perlakuan dengan 10 ulangan dan setiap ulangan berisi 1 ekor yang ditempatkan secara acak pada kandang system baterai. Perlakuan terdiri dari P0 (ransum kontrol), P1 ( ransum kontrol + $15 \%$ lumpur sawit fermentasi (LSF), P2 (ransum kontrol + 15 \% LSF +6 g/kg ekstrak daun katuk (EDK), P3 (Ransum kontrol + 15 $\%$ LSF+ $9 \mathrm{~g} / \mathrm{kg}$ EDK) dan P4 (ransum kontrol + $15 \%$ LSF + $12 \mathrm{~g} / \mathrm{kg}$ EDK). Hasil penelitian menunjukkan bahwa suplementasi EDK dalam ransum berbasis lumpur sawit fermentasi berpengaruh tidak nyata terhadap konsumsi ransum $(\mathrm{P}>0.05)$ tetapi berpengaruh nyata $(\mathrm{P}<0.01)$ terhadap produksi telur $(\%)$, produksi telur (butir/ekor), produksi telur (gram/ekor) dan berpengaruh nyata terhadap nilai konversi ransum $(\mathrm{P}<0.05)$. Level suplementasi EDK (ekstrak daun katuk) terbaik yaitu $6 \mathrm{~g} / \mathrm{kg}$ ransum. Dapat disimpulkan bahwa suplementasi ekstrak daun katuk (Sauropus androgynus) sebanyak $6 \mathrm{~g} / \mathrm{kg}$ ransum dalam ransum berbasis lumpur sawit fermentasi (LSF) terhadap performans ayam ras petelur tidak meningkatkan konsumsi ransum namun dapat meningkatkan produksi telur dan memperbaiki konversi ransum.
\end{abstract}

Kata Kunci : Lumpur Sawit Fermentasi, Ekstrak Daun Katuk, Performans Ayam Petelur

\section{PENDAHULUAN}

Target konsumsi protein hewani asal ternak di Indonesia sebesar 6 $\mathrm{g} /$ kapita/hari yang setara dengan daging $10,1 \mathrm{~kg} / \mathrm{kapita} / \mathrm{tahun}$, telur 3,5 $\mathrm{kg} / \mathrm{kapita} / \mathrm{tahun}$ dan susu 6,4 
kg/kapita/tahun (Rusfidra, 2010) masih belum bisa dicapai. Untuk mempercepat pencapaian target tersebut sektor peternakan harus melakukan pengembangan berbagai industri peternakan. Pengembangan industri ayam petelur merupakan salah satu alternatif sebagai penyedia protein hewani yang relatif cepat dan murah.

$$
\text { Pengembangan industri }
$$

peternakan ayam petelur di Indonesia masih dihadapkan pada berbagai tantangan antara lain tuntutan konsumen yang menghendaki produk ternak unggas yang bermutu tinggi. Salah satu masalah yang dihadapi dalam pengembangan industri ayam petelur adalah efisiensi produksi ayam petelur yang masih rendah. Penyebab utama rendahnya efisiensi produksi ini adalah akibat dari tingginya harga pakan impor (bungkil kedelai, jagung dan tepung ikan) serta adanya ketersediaan bahan pakan berkualitas tinggi yang terbatas sehingga diperlukan bahan pakan alternatif. Salah satu bahan pakan yang berpotensi untuk hal ini adalah lumpur sawit yang difermentasi. Penggunaan lumpur sawit ini didasarkan pada harga lumpur sawit yang relatif murah dan tersedia sepanjang tahun seiring dengan meningkatnya produksi minyak sawit Indonesia (Bintang et al., 2003). Namun, kandungan protein kasar lumpur sawit masih rendah dikarenakan lumpur sawit merupakan produk sampingan dari pengolahan minyak sawit.

Berdasarkan penelitian Sinurat (2003), kandungan protein kasar lumpur minyak sawit kering sekitar 9,6 \% - 14, 52 $\%$ hampir sama dengan kandungan protein kasar dedak padi, yaitu 13,3\%. Untuk itu perlu dilakukan proses lanjut berupa fermentasi dengan kapang untuk meningkatkan protein kasar dan menurunkan serat kasar lumpur sawit. Berdasarkan hasil penelitian Fenita et al. (2010), kandungan protein kasar lumpur sawit yang difermentasikan dengan Neurospora crasa mengalami peningkatan yang signifikan mencapai 23,45 \% dengan komposisi kandungan nutrisi total yaitu protein kasar 23,45\%, serat kasar 17,34\%, energi (ME) $1774 \mathrm{kkal} / \mathrm{kg}$, Ca $1,32 \%$, dan $\mathrm{P}$ 0,56 \% sedangkan lumpur sawit yang difermentasi dengan kapang Aspergillus niger memiliki kandungan protein kasar 22,07 \%, serat kasar 18,6 \%, energi (ME) $1717 \mathrm{kkal} / \mathrm{kg}$, Ca 1,24 \% dan P 0,65 \% (Sinurat, 2003).

Fenita et al. (2010) menemukan bahwa pemberian lumpur sawit fermentasi pada level 15\% dalam ransum ayam petelur memberikan produksi terbaik, berat telur tertinggi dan konversi ransum terendah dibanding dengan perlakuan kontrol tanpa lumpur sawit fermentasi. Palinka (2010) juga melaporkan bahwa pemberian lumpur sawit fermentasi pada taraf $15 \%$ tidak memberikan efek yang negatif terhadap efisiensi penggunaan ransum.

Menurut Akbar (2010), pakan berbasis lumpur sawit dengan pemberian asam amino $75 \%$ dari yang direkomendasikan berpengaruh nyata terhadap konsumsi pakan, konversi ransum dan berat telur yang dihasilkan juga maksimal jika dibandingkan dengan perlakuan kontrol, perlakuan $50 \%$ dan $100 \%$ pemberian asam amino. Namun pemberian lumpur sawit fermentasi dalam ransum ayam petelur masih terbatas dikarenakan adanya kandungan serat kasar yang tinggi serta defisien terhadap asam amino esensial seperti 
lisin dan metionin (Fenita et al., 2010). Belum optimalnya lumpur sawit fermentasi dalam peningkatan performans ayam petelur dapat diatasi dengan suplementasi bahan tambahan. Salah satu bahan pakan tambahan yang berpotensi untuk tujuan tersebut adalah ekstrak daun katuk (EDK).

Sauropus androgynus (katuk) merupakan suplemen yang potensial dikarenakan katuk termasuk tumbuhan obat yang kaya akan $\beta$-karoten (Yulianis dan Marwati, 1997). Selain itu, katuk mempunyai sifat antibakteri (Darise dan Sulaeman, 1997; Santoso, 2001; Santoso et al., 2001), kaya akan mineral (Santoso dan Sartini, 2001; Santoso et al., 2002) dan tinggi akan vitamin $C$ serta kaya akan asam amino esensial. Ekstrak daun katuk juga mengandung asam benzoat yang bisa dikonversi menjadi estradiol benzoat didalam tubuh ayam (Santoso et al., 2005). Ekstrak daun katuk berperan untuk meningkatkan fungsi reproduksi dan merangsang pertumbuhan folikel sehingga ayam dapat meningkatkan produksi telur yang lebih tinggi dan lebih efisien (Santoso et al., 2003 ; 2005). Hasil penelitian pada broiler menunjukkan bahwa pemberian ekstrak daun katuk mampu meningkatkan warna kuning pada kulit broiler (Santoso et al., 2001). Hal ini disebabkan daun katuk kaya akan $\beta$-karoten. Daun katuk memiliki kandungan protein 6,64 \%, lemak 1,76 \%, serat kasar 2,18 \%, air 78,21 $\%$, dan 2,04 \% abu (Djojosoebagio, 1994).

$$
\text { Berdasarkan hasil penelitian }
$$
Saparingga (2012), pemberian suplementasi ekstrak daun katuk (Sauropus androgynus) pada ayam burgo melalui air minum dengan konsentrasi 0,9-2,7 g/ekor/hari dapat meningkatkan berat telur, indeks yolk, indeks albumen dan warna kuning telur tetapi tidak meningkatkan jumlah produksi telur. Ayam petelur yang diberi EDK ke dalam ransum sebanyak 4,5 g menghasilkan peningkatan produksi telur sebesar yaitu $36,4 \%$ dan 9 g EDK ke dalam ransum meningkatkan $31,8 \%$ produksi telur dari pakan kontrol (Santoso dan Suharyanto, 2010).

Dengan demikian, tuntutan konsumen akan bobot telur yang tinggi dengan performans produksi yang tinggi diduga dapat dipenuhi dengan cara menambahkan ekstrak daun katuk (Sauropus androgynus) ke dalam ransum berbasis lumpur sawit fermentasi pada ayam ras petelur.

Penelitian ini bertujuan untuk mengevaluasi pengaruh suplementasi ekstrak daun katuk (Sauropus androgynus) didalam ransum berbasis lumpur sawit fermentasi terhadap performans ayam ras petelur.

\section{MATERI DAN METODE}

Penelitian ini dilaksanakan pada 1 Mei sampai 26 Juni 2012 dengan lokasi di Kandang Jurusan Peternakan Universitas Bengkulu.

Pada penelitian ini ada 2 tahap dalam persiapan pakan penelitian yaitu pembuatan pakan lumpur sawit fermentasi dengan kapang Neurspora $s p$ dan pembuatan ekstrak daun katuk (Sauropus androgynus).

\section{Pembuatan Lumpur Sawit Fermentasi}

Lumpur sawit yang sudah dikeringkan ditambahkan aquades (kadar air $70 \%$ ) kemudian diaduk secara merata. Setelah itu dikukus selama 45 
menit sampai air mendidih untuk mensterilkan bahan. Kemudian bahan yang sudah steril tersebut didinginkan mencapai suhu kamar. Selanjutnya bahan diinokulasi dengan kapang Neurospora $s p$ dan diaduk secara merata. Kemudian diinkubasi selama 7 hari (5 hari secara aerob dan 2 hari secara anaerob). Setelah itu produk fermentasi dipanen, dikeringkan dengan menggunakan sinar matahari dan digiling yang kemudian dicampurkan ke dalam ransum sebanyak $15 \%$ dari total ransum yang diberikan (Fenita et al., 2010).

\section{Pembuatan ekstrak daun katuk}

Daun katuk dikeringanginkan sampai kering kemudian daun katuk direbus selama 30 menit dengan suhu $60^{\circ} \mathrm{C}$ dengan perbandingan air dan katuk $1: 5$. Kemudian daun katuk disaring dan airnya direbus selama 12 jam (sampai menjadi ekstrak daun katuk yang kental) pada suhu $60^{\circ} \mathrm{C}$ (Santoso et al.. 2003; 2005).

Rancangan acak lengkap (RAL) digunakan dalam penelitian ini. Adapun ayam petelur yang digunakan terdiri dari 50 ekor ayam petelur umur 16 bulan yang terbagi kedalam 5 perlakuan yaitu:

$$
\begin{aligned}
\mathrm{P} 0= & \text { Ransum Kontrol (RK) } \\
\mathrm{P} 1= & \mathrm{RK}+15 \% \text { Lumpur } \\
& \text { Fermentasi } \\
\mathrm{P} 2= & \mathrm{RK}+15 \% \text { Lumpur } \\
& \text { Fermentasi }+6 \text { g Ekstrak } \\
& \text { Katuk } \\
\mathrm{P} 3= & \mathrm{RK}+15 \% \text { Lumpur } \\
& \text { Fermentasi }+9 \mathrm{~g} \text { Ekstrak Daun } \\
& \text { Katuk }
\end{aligned}
$$
$\mathrm{P} 4=\mathrm{RK}+15 \%$ Lumpur Sawit Fermentasi +12 g Ekstrak Daun Katuk

Setiap perlakuan terdiri dari 10 ulangan. Setiap ulangan berisi 1 ekor ayam petelur yang diletakkan di dalam kandang baterai individual secara acak (Individual cage). Ransum dan air minum diberikan secara ad-libitum. Adapun variabel yang diamati terdiri dari konsumsi ransum, produksi telur (\%), produksi telur (butir/ekor), produksi telur (gram/ekor) dan konversi ransum.

Semua data dianalisis varians dan jika berbeda nyata dilanjutkan dengan uji lanjut DMRT.

\section{HASIL DAN PEMBAHASAN}

\section{Konsumsi ransum}

Jumlah konsumsi ransum ayam petelur dari minggu pertama sampai minggu ke delapan dan selama penelitian dari setiap perlakuan disajikan pada tabel 1.

Berdasarkan hasil sidik ragam, suplementasi ekstrak daun katuk (Sauropus androgynus) dalam ransum berbasis lumpur sawit fermentasi berpengaruh tidak nyata $(\mathrm{P}>0,05)$ terhadap konsumsi ransum ayam petelur pada minggu pertama, kedua, keempat, kelima, keenam, ketujuh, ke delapan dan selama penelitian (Tabel 1) sedangkan pada minggu ketiga penelitian suplementasi EDK dalam ransum berbasis lumpur sawit fermentasi berpengaruh nyata terhadap konsumsi ransum $(\mathrm{P}<0,01)$.

Berdasarkan hasil uji DMRT untuk minggu ketiga menunjukkan bahwa P1 berbeda nyata terhadap P0, P2 dan P3 tetapi berbeda tidak nyata terhadap $\mathrm{P} 4$ 
Tabel 1. Pengaruh suplementasi ekstrak daun katuk (Sauropus androgynus) dalam ransum berbasis lumpur sawit fermentasi terhadap konsumsi ransum ayam petelur

\begin{tabular}{|c|c|c|c|c|c|c|c|}
\hline \multirow{2}{*}{ Minggu } & \multicolumn{5}{|c|}{ Konsumsi Ransum (g/ekor) } & \multirow{2}{*}{ SD } & \multirow{2}{*}{$\mathrm{P}$} \\
\hline & P0 & $\mathrm{P} 1$ & $\mathrm{P} 2$ & P3 & $\mathrm{P} 4$ & & \\
\hline 1 & 823,37 & 850,08 & 877,47 & 834,26 & 799,93 & 78,04 & ns \\
\hline 2 & 873,50 & 831,47 & 882,01 & 868,54 & 821,29 & 57,07 & ns \\
\hline 3 & $878,17 \mathrm{a}$ & $795,27^{b}$ & $886,02^{a}$ & $885,73^{a}$ & $845,22^{a b}$ & 68,98 & * \\
\hline 4 & 849,25 & 827,19 & 825,50 & 848,89 & 814,67 & 82,01 & ns \\
\hline 5 & 868,95 & 856,45 & 763,04 & 842,03 & 800,58 & 97,50 & ns \\
\hline 6 & 835,49 & 832,55 & 865,25 & 871,45 & 831,63 & 74,45 & ns \\
\hline 7 & 811,57 & 841,46 & 868,71 & 864,65 & 805,04 & 77,98 & ns \\
\hline 8 & 661,96 & 823,04 & 885,46 & 849,40 & 698,15 & 153,24 & ns \\
\hline Total Selama Penelitian & 6602,27 & 6657,50 & 6853,45 & 6864,95 & 6416,51 & 499,72 & ns \\
\hline
\end{tabular}

\section{Keterangan :}

ns : menunjukkan perlakuan berbeda tidak nyata $(\mathrm{P}>0,05)$

superskrip berbeda pada baris rataan yang sama menunjukkan perlakuan berbeda sangat nyata $(\mathrm{P}<0,01)$

P0 = ransum kontrol, P1 = ransum kontrol + 15\% lumpur sawit fermentasi (LSF), P2 = ransum kontrol + $15 \%$

LSF + ekstrak daun katuk (EDK) 6 g/kg ransum, P3 = ransum kontrol + $15 \%$ LSF + EDK 9 g/kg ransum, P4 =

ransum kontrol + 15 \% LSF + EDK 12 g/kg ransum

sedangkan P4 berbeda tidak nyata terhadap semua perlakuan.

Hasil penelitian ini berbeda dengan hasil penelitian Fenita et al. (2010) yang menemukan bahwa pemberian lumpur sawit fermentasi sebanyak $15 \%$ menurunkan konsumsi ransum. Perbedaan ini diduga dikarenakan oleh perbedaan spesies mikrobia yang digunakan dalam fermentasi. Selain itu tingkat energi dan protein ransum yang digunakan juga memberikan pengaruh terhadap konsumsi ransum. Menurut Palinka (2010), faktor utama yang mempengaruhi konsumsi ransum adalah tingkat energi ransum yang diberikan. Pada penelitian ini tingkat energi ransum yang diberikan pada setiap perlakuan relatif sama.

\section{Produksi Telur}

Produksi telur (\%) yang dihasilkan pada minggu pertama sampai minggu ke delapan dan selama penelitian dari setiap perlakuan disajikan pada tabel 2 .

Berdasarkan hasil sidik ragam, suplementasi ekstrak daun katuk (Sauropus androgynus) dalam ransum berbasis lumpur sawit fermentasi berpengaruh nyata $(\mathrm{P}<0,01)$ terhadap persentase produksi telur ayam petelur pada minggu kedua, ketiga, kelima dan selama penelitian (Tabel 2). Pada minggu pertama, keempat, enam, tujuh dan delapan suplementasi EDK dalam ransum berbasis lumpur sawit fermentasi berbeda tidak nyata antar perlakuan $(\mathrm{P}>0,05)$.

Hasil uji DMRT untuk persentase produksi telur selama penelitian menunjukkan bahwa P1 berbeda nyata 
ISSN 1978 - 3000

Tabel 2. Pengaruh suplementasi ekstrak daun katuk (Sauropus androgynus) dalam ransum berbasis lumpur sawit fermentasi terhadap produksi telur ayam petelur

\begin{tabular}{|c|c|c|c|c|c|c|c|}
\hline \multirow{2}{*}{ Minggu } & \multicolumn{5}{|c|}{ Produksi Telur (\%) } & \multirow{2}{*}{ SD } & \multirow{2}{*}{$\mathrm{P}$} \\
\hline & P0 & P1 & $\mathrm{P} 2$ & P3 & $\mathrm{P} 4$ & & \\
\hline 1 & 71,50 & 48,70 & 80,00 & 61,40 & 68,70 & 25,63 & ns \\
\hline 2 & $82,80^{a}$ & $44,30^{\mathrm{b}}$ & $75,80^{\mathrm{a}}$ & $63,00^{\mathrm{ab}}$ & $62,70^{\mathrm{ab}}$ & 23,45 & * \\
\hline 3 & $87,20^{a}$ & $47,20^{\mathrm{b}}$ & $85,80^{a}$ & $75,60^{a}$ & $70,00^{\mathrm{ab}}$ & 23,59 & * \\
\hline 4 & 77,10 & 54,30 & 75,50 & 77,10 & 70,10 & 22,76 & ns \\
\hline 5 & $85,80^{a}$ & $44,20^{\mathrm{b}}$ & $75,70^{\mathrm{ab}}$ & $71,50^{\mathrm{ab}}$ & $68,60^{\mathrm{ab}}$ & 30,92 & * \\
\hline 6 & 84,20 & 72,80 & 80,10 & 71,30 & 75,80 & 21,05 & ns \\
\hline 7 & 87,30 & 60,00 & 88,60 & 78,60 & 74,40 & 25,07 & ns \\
\hline 8 & 70,00 & 57,10 & 85,70 & 75,70 & 61,50 & 26,52 & ns \\
\hline elama Penelitian & $80,54^{a}$ & $53,57^{b}$ & $80,89^{a}$ & $71,79 \mathrm{ab}$ & $68,93^{\mathrm{ab}}$ & 18,69 & * \\
\hline
\end{tabular}

Keterangan :

ns : menunjukkan perlakuan berbeda tidak nyata $(\mathrm{P}>0,05)$

superskrip berbeda pada baris rataan yang sama menunjukkan perlakuan berbeda sangat nyata $(\mathrm{P}<0,01)$

$\mathrm{P} 0=$ ransum kontrol, $\mathrm{P} 1$ = ransum kontrol + 15\% lumpur sawit fermentasi (LSF), P2 = ransum kontrol + $15 \%$ LSF + ekstrak daun katuk (EDK) $6 \mathrm{~g} / \mathrm{kg}$ ransum, P3 = ransum kontrol + $15 \%$ LSF + EDK $9 \mathrm{~g} / \mathrm{kg}$ ransum, P4 = ransum kontrol + $15 \% \mathrm{LSF}+\mathrm{EDK} 12 \mathrm{~g} / \mathrm{kg}$ ransum

terhadap P0 dan P2 tetapi berbeda tidak nyata terhadap P3 dan P4 sedangkan P3 dan P4 berbeda tidak nyata terhadap P0 dan P2. Untuk minggu kedua, P1 berbeda nyata terhadap P0 dan P2 tetapi berbeda tidak nyata terhadap P3 dan P4 sedangkan P3 dan P4 berbeda tidak nyata terhadap P0 dan P2. Pada minggu ketiga penelitian menunjukkan bahwa P1 berbeda nyata terhadap P0, P2 dan P3 tetapi berbeda tidak nyata terhadap $\mathrm{P} 4$ sedangkan $\mathrm{P} 4$ berbeda tidak nyata terhadap P0, P2 dan P3. Selanjutnya pada minggu kelima penelitian menunjukkan bahwa P1 berbeda nyata terhadap P0 tetapi tidak berbeda nyata terhadap P2, P3 dan P4 sedangkan P0 berbeda tidak nyata terhadap P2, P3 dan P4.

Berdasarkan hasil penelitian ini, pemberian lumpur sawit fermentasi menurunkan persentase produksi. Hal ini dikarenakan lumpur sawit mengandung serat kasar yang cukup tinggi dan defisien akan asam amino esensial (Fenita et al., 2010). Suplementasi ekstrak daun katuk memperbaiki persentase produksi pada ayam petelur yang diberi lumpur sawit fermentasi. Suplementasi EDK sebesar $6 \quad \mathrm{~g} / \mathrm{kg}$ ransum memberikan persentase produksi yang sebanding dengan kontrol (P0). Hasil penelitian ini sesuai dengan hasil penelitian santoso dan Suharyanto (2010), pemberian EDK didalam ransum sebanyak 4,5 g dan $9 \mathrm{~g}$ mampu meningkatkan produksi telur dibandingkan dengan perlakuan kontrol. Hal ini dikarenakan adanya kandungan asam benzoate didalam daun katuk (Santoso et al., 2003; 2005) yang dapat dikonversi menjadi estradiol (Suprayogi et al., 2001) sehingga dapat meningkatkan dan memperbaiki 
performans reproduksi ayam petelur (Santoso et al., 2003). Selain itu juga tingginya kandungan asam amino esensial lisin dan metionin dalam daun katuk (Santoso et al., 2004) dapat mencukupi kebutuhan asam amino esensial yang defisien pada lumpur sawit fermentasi sehingga mampu meningkatkan produksi ayam petelur.Produksi telur (butir) pada minggu pertama sampai minggu ke delapan dan selama penelitian dari setiap perlakuan disajikan pada tabel 3.

Berdasarkan hasil sidik ragam, suplementasi ekstrak daun katuk (Sauropus androgynus) dalam ransum berbasis lumpur sawit fermentasi berpengaruh nyata $(\mathrm{P}<0,01)$ terhadap produksi telur ayam petelur pada minggu kedua, ketiga, kelima dan selama penelitian dalam satuan butir (Tabel 3) sedangkan pada minggu pertama, keempat, keenam, ketujuh dan ke delapan suplementasi EDK dalam ransum berbasis lumpur sawit fermentasi berpengaruh tidak nyata terhadap produksi telur dalam butir $(\mathrm{P}>0,05)$.

Hasil uji DMRT untuk produksi telur dalam butir selama penelitian menunjukkan bahwa P1 berbeda nyata terhadap P0 dan P2 tetapi berbeda tidak nyata terhadap P3 dan P4 sedangkan P3 dan P4 berbeda tidak nyata terhadap P0 dan P2. Untuk minggu kedua, P1 berbeda nyata terhadap P0 dan P2 tetapi berbeda tidak nyata terhadap P3 dan P4 sedangkan P3 dan P4 berbeda tidak nyata terhadap P0 dan P2. Pada minggu ketiga penelitian menunjukkan bahwa P1 berbeda nyata terhadap P0, P2, P3 dan P4. Selanjutnya pada minggu kelima penelitian menunjukkan bahwa P1 berbeda nyata terhadap P0 tetapi tidak berbeda nyata terhadap P2, P3 dan P4 sedangkan P0 berbeda tidak nyata terhadap P2, P3 dan P4.

Berdasarkan penelitian Akbar

Tabel 3. Pengaruh suplementasi ekstrak daun katuk (Sauropus androgynus) dalam ransum berbasis lumpur sawit fermentasi terhadap produksi telur ayam petelur

\begin{tabular}{|c|c|c|c|c|c|c|c|}
\hline \multirow{2}{*}{ Minggu } & \multicolumn{5}{|c|}{ Produksi Telur (butir/ekor) } & \multirow{2}{*}{ SD } & \multirow{2}{*}{$\mathrm{P}$} \\
\hline & $\mathrm{P} 0$ & P1 & $\mathrm{P} 2$ & P3 & $\mathrm{P} 4$ & & \\
\hline 1 & 5 & 3 & 6 & 4 & 5 & 1,79 & Ns \\
\hline 2 & $6^{\mathrm{a}}$ & $3^{\mathrm{b}}$ & $5^{a}$ & $4^{\mathrm{ab}}$ & $4^{\mathrm{ab}}$ & 1,64 & * \\
\hline 3 & $6^{a}$ & $3^{\mathrm{b}}$ & $6^{a}$ & $5^{\mathrm{a}}$ & $5^{\mathrm{a}}$ & 1,65 & * \\
\hline 4 & 5 & 4 & 5 & 5 & 5 & 1,57 & Ns \\
\hline 5 & $6^{\mathrm{a}}$ & $3^{b}$ & $5^{\mathrm{ab}}$ & $5^{\mathrm{ab}}$ & $5^{\mathrm{ab}}$ & 2,16 & * \\
\hline 6 & 6 & 5 & 6 & 5 & 5 & 1,47 & Ns \\
\hline 7 & 6 & 4 & 6 & 6 & 5 & 1,75 & Ns \\
\hline 8 & 5 & 4 & 6 & 5 & 4 & 1,85 & Ns \\
\hline elama Penelitian & $45^{\mathrm{a}}$ & $30^{b}$ & $45^{\mathrm{a}}$ & $40^{\mathrm{ab}}$ & $39^{a b}$ & 10,47 & * \\
\hline
\end{tabular}

\section{Keterangan :}

ns : menunjukkan perlakuan berbeda tidak nyata $(\mathrm{P}>0,05)$

superskrip berbeda pada baris rataan yang sama menunjukkan perlakuan berbeda sangat nyata $(\mathrm{P}<0,01)$

$\mathrm{P} 0=$ ransum kontrol, P1 = ransum kontrol $+15 \%$ lumpur sawit fermentasi (LSF), P2 = ransum kontrol $+15 \%$ LSF + ekstrak daun katuk (EDK) $6 \mathrm{~g} / \mathrm{kg}$ ransum, P3 = ransum kontrol + $15 \%$ LSF + EDK $9 \mathrm{~g} / \mathrm{kg}$ ransum, P4 = ransum kontrol + $15 \%$ LSF + EDK $12 \mathrm{~g} / \mathrm{kg}$ ransum 
(2010), pakan perlakuan yang disuplementasi dengan asam amino esensial dalam ransum berbasis lumpur sawit fermentasi mampu meningkatkan produksi telur dengan taraf pemberian $50 \%, 75 \%$ dan $100 \%$ asam amino jika dibandingkan dengan perlakuan kontrol. Pada penelitian ini, perlakuan yang disuplementasi dengan EDK dengan level pemberian $6 \mathrm{~g} / \mathrm{kg}$ ransum dan 9 $\mathrm{g} / \mathrm{kg}$ ransum mampu meningkatkan produksi telur. Berbeda dengan penelitian Saparingga (2012), suplementasi EDK melalui air minum pada ayam burgo sebesar 0,9-2,7 g/ekor/hari belum meningkatkan jumlah produksi telur.

Produksi massa telur (gram) pada minggu pertama sampai minggu ke delapan dan selama penelitian dari setiap perlakuan disajikan pada tabel 4 .

Berdasarkan analisis ANOVA, suplementasi ekstrak daun katuk
(Sauropus androgynus) dalam ransum berbasis lumpur sawit fermentasi berpengaruh nyata $(\mathrm{P}<0,01)$ terhadap produksi massa telur ayam petelur pada minggu pertama, kedua, ketiga dan selama penelitian dalam satuan gram (Tabel 4) sedangkan pada minggu keempat, kelima, keenam, ketujuh dan ke delapan suplementasi EDK dalam ransum berbasis lumpur sawit fermentasi berbeda tidak nyata $(\mathrm{P}>0,05)$ terhadap produksi massa telur.

Hasil uji DMRT untuk produksi massa telur selama penelitian menunjukkan bahwa P1 berbeda nyata terhadap P0 dan P2 tetapi berbeda tidak nyata terhadap P3 dan P4 sedangkan P3 dan $\mathrm{P} 4$ berbeda tidak nyata terhadap P0 dan P2. Pada minggu pertama menunjukkan bahwa P1 berbeda nyata terhadap P2 tetapi berbeda tidak nyata terhadap P0, P3 dan P4 sedangkan P2 berbeda tidak nyata terhadap P0, P3 dan

Tabel 4. Pengaruh suplementasi ekstrak daun katuk (Sauropus androgynus) dalam ransum berbasis lumpur sawit fermentasi terhadap produksi telur ayam petelur

\begin{tabular}{cccccccc}
\hline \multirow{2}{*}{ Minggu } & \multicolumn{9}{c}{ Produksi Telur (g/ekor) } & SD & P \\
\cline { 2 - 6 } & P0 & P1 & P2 & P3 & P4 & & \\
\hline & $326,20^{\mathrm{ab}}$ & $215,26^{\mathrm{b}}$ & $369,62^{\mathrm{a}}$ & $282,33^{\mathrm{ab}}$ & $309,97 \mathrm{ab}$ & 144,61 & $*$ \\
2 & $366,99^{\mathrm{a}}$ & $191,78^{\mathrm{b}}$ & $327,40^{\mathrm{a}}$ & $284,26^{\mathrm{ab}}$ & $282,04^{\mathrm{ab}}$ & 108,22 & $*$ \\
3 & $393,48^{\mathrm{a}}$ & $215,82^{\mathrm{b}}$ & $373,50^{\mathrm{a}}$ & $343,74^{\mathrm{a}}$ & $312,88^{\mathrm{ab}}$ & 101,69 & $*$ \\
4 & 372,88 & 263,14 & 342,47 & 359,82 & 320,79 & 98,32 & $\mathrm{~ns}$ \\
5 & 398,37 & 201,81 & 332,31 & 330,02 & 318,21 & 150,42 & $\mathrm{~ns}$ \\
7 & 389,53 & 329,89 & 354,13 & 329,31 & 350,61 & 101,4 & $\mathrm{~ns}$ \\
8 & 399,10 & 272,77 & 395,18 & 373,86 & 338,42 & 117,02 & $\mathrm{~ns}$ \\
\hline Total Selama Penelitian & $2964,96^{\mathrm{a}}$ & $1949,69^{\mathrm{b}}$ & $2891,36^{\mathrm{a}}$ & $2654,21^{\mathrm{ab}}$ & $2509,34^{\mathrm{ab}}$ & 691,53 & $*$ \\
\hline
\end{tabular}

\footnotetext{
Keterangan :
}

ns : menunjukkan perlakuan berbeda tidak nyata $(\mathrm{P}>0,05)$

superskrip berbeda pada baris rataan yang sama menunjukkan perlakuan berbeda sangat nyata $(\mathrm{P}<0,01)$

$\mathrm{P0}=$ ransum kontrol, $\mathrm{P} 1$ = ransum kontrol $+15 \%$ lumpur sawit fermentasi (LSF), P2 = ransum kontrol + $15 \%$

LSF + ekstrak daun katuk (EDK) $6 \mathrm{~g} / \mathrm{kg}$ ransum, P3 = ransum kontrol + $15 \%$ LSF + EDK $9 \mathrm{~g} / \mathrm{kg}$ ransum, P4 = ransum kontrol + $15 \% \mathrm{LSF}+\mathrm{EDK} 12 \mathrm{~g} / \mathrm{kg}$ ransum 
P4. Pada minggu kedua, hasil uji DMRT menunjukkan bahwa P1 berbeda nyata terhadap P0 dan P2 tetapi berbeda tidak nyata terhadap P3 dan P4 sedangkan P3 dan P4 berbeda tidak nyata terhadap P0 dan P2. Pada minggu ketiga, uji DMRT menunjukkan bahwa P1 berbeda nyata terhadap P0, P2 dan P3 tetapi berbeda tidak nyata terhadap $\mathrm{P} 4$ sedangkan $\mathrm{P} 4$ berbeda tidak nyata terhadap P0, P2 dan P3.

Pada penelitian ini, produksi massa telur pada perlakuan dengan suplementasi EDK $6 \mathrm{~g} / \mathrm{kg}$ ransum (P2) sebanding dengan produksi massa telur pada perlakuan kontrol (PO) sedang pada perlakuan tanpa suplementasi EDK (P1) memberikan hasil produksi massa terendah. Hal ini menunjukkan bahwa suplementasi EDK dalam ransum berbasis lumpur sawit fermentasi memberikan pengaruh positif terhadap produksi massa ayam petelur.
Berdasarkan penelitian Fenita et al. (2010), perlakuan pakan LSF belum meningkatkan produksi massa telur. Sesuai dengan penelitian ini bahwa perlakuan LSF $15 \%$ tanpa suplementasi EDK justru menurunkan produksi massa sehingga diduga ada kandungan tertentu didalam EDK yang mampu meningkatkan produksi massa.

\section{Konversi Ransum}

Konversi ransum pada minggu pertama sampai minggu ke delapan dan selama penelitian dari setiap perlakuan disajikan pada tabel 5.

Berdasarkan analisis ANOVA, suplementasi ekstrak daun katuk (Sauropus androgynus) dalam ransum berbasis lumpur sawit fermentasi berpengaruh nyata $(\mathrm{P}<0,05)$ terhadap konversi ransum ayam petelur pada minggu pertama, kedua, ketiga keempat, kelima dan selama penelitian dalam

Tabel 5. Pengaruh suplementasi ekstrak daun katuk (Sauropus androgynus) dalam ransum berbasis lumpur sawit fermentasi terhadap konversi ransum ayam petelur

\begin{tabular}{|c|c|c|c|c|c|c|c|}
\hline \multirow{2}{*}{ Minggu } & \multicolumn{5}{|c|}{ Konversi Ransum } & \multirow{2}{*}{$\mathrm{SD}$} & \multirow{2}{*}{$\mathrm{P}$} \\
\hline & P0 & $\mathrm{P} 1$ & $\mathrm{P} 2$ & P3 & $\mathrm{P} 4$ & & \\
\hline 1 & $2,90^{\mathrm{b}}$ & $5,57^{a}$ & $2,47^{b}$ & $3,98^{\mathrm{ba}}$ & $2,94^{b}$ & 2,56 & * \\
\hline 2 & $2,52^{\mathrm{b}}$ & $5,15^{\mathrm{a}}$ & $2,90^{\mathrm{b}}$ & $3,57^{\mathrm{ba}}$ & $3,10^{\mathrm{b}}$ & 1,90 & * \\
\hline 3 & $2,26^{a}$ & $5,05^{b}$ & $2,39 a$ & $2,71^{\mathrm{ab}}$ & $3,04^{\mathrm{ab}}$ & 1,85 & * \\
\hline 4 & $2,30^{\mathrm{b}}$ & $4,27^{a}$ & $2,51^{b}$ & $2,44^{\mathrm{b}}$ & $2,48^{b}$ & 1,75 & * \\
\hline 5 & $2,33^{b}$ & $7,38^{a}$ & $3,12^{b}$ & $2.71^{\mathrm{b}}$ & $2.46^{\mathrm{b}}$ & 3,40 & * \\
\hline 6 & 2,20 & 2,82 & 2,62 & 3,82 & 2,60 & 1,94 & Ns \\
\hline 7 & 2,05 & 4,13 & 2,26 & 2,22 & 2,44 & 1,83 & Ns \\
\hline 8 & 2,16 & 4,13 & 2,28 & 3,24 & 2,95 & 2,05 & $\mathrm{Ns}$ \\
\hline Total Selama Penelitian & $2,24^{\mathrm{b}}$ & $3,95^{\mathrm{a}}$ & $2,41^{b}$ & $2,88^{\mathrm{b}}$ & $2,68^{b}$ & 1,11 & * \\
\hline
\end{tabular}

Keterangan :

ns : menunjukkan perlakuan berbeda tidak nyata $(\mathrm{P}>0,05)$

superskrip berbeda pada baris rataan yang sama menunjukkan perlakuan berbeda nyata $(\mathrm{P}<0,05)$

$\mathrm{P} 0=$ ransum kontrol, $\mathrm{P} 1$ = ransum kontrol $+15 \%$ lumpur sawit fermentasi (LSF), P2 = ransum kontrol $+15 \%$ LSF + ekstrak daun katuk (EDK) $6 \mathrm{~g} / \mathrm{kg}$ ransum, P3 = ransum kontrol + $15 \%$ LSF + EDK $9 \mathrm{~g} / \mathrm{kg}$ ransum, P4 = ransum kontrol + $15 \%$ LSF + EDK $12 \mathrm{~g} / \mathrm{kg}$ ransum 
satuan gram (Tabel 5) sedangkan pada minggu keenam, ketujuh dan ke delapan suplementasi EDK dalam ransum berbasis lumpur sawit fermentasi berbeda tidak nyata $(P>0,05)$ terhadap konversi ransum.

Hasil uji DMRT selama penelitian menunjukkan bahwa P1 berbeda nyata terhadap semua perlakuan (P0, P2, P3 dan P4). Pada minggu pertama, hasil uji DMRT menunjukkan bahwa P1 berbeda nyata terhadap P0, P2 dan P4 tetapi berbeda tidak nyata terhadap P3 sedangkan P3 berbeda tidak nyata terhadap P0, P2 dan P4. Untuk minggu kedua sampai minggu kelima, uji DMRT menunjukkan bahwa $\mathrm{P} 1$ berbeda nyata terhadap semua perlakuan (P0, P2, P3, P4).

Hasil penelitian menunjukkan suplementasi lumpur sawit fermentasi menurunkan efisiensi produksi yang ditunjukkan oleh tingginya konversi ransum. Suplementasi EDK dalam ransum berbasis lumpur sawit fermentasi memperbaiki konversi ransum. Level suplementasi EDK yang paling efisien adalah sebesar $6 \mathrm{~g} / \mathrm{kg}$ ransum. Hasil penelitian ini sesuai dengan hasil penelitian Santoso et al. (2005) yang menemukan bahwa suplementasi EDK dalam ransum memperbaiki konversi pakan.

$$
\text { Menurut Suprayogi (2000; }
$$

Suprayogi et al., 2001), daun katuk mengandung androstan-17-one,3-ethyl3-hydroxy-5 alpha yang dapat dikonversikan menjadi estradiol. Putranto (2011) juga menemukan bahwa suplementasi ekstrak daun katuk meningkatkan konsentrasi hormon estradiol-17 $\beta$ (E2) dalam serum pada ayam Burgo. Menurut Santoso et al.
(2003), daun katuk kaya akan asam benzoat yang dapat dikonversikan menjadi estradiol benzoat yang mempunyai peranan memperbaiki performans alat reproduksi.

\section{SIMPULAN}

Berdasarkan hasil penelitian dapat disimpulkan bahwa suplementasi ekstrak daun katuk (Sauropus androgynus) sebesar $6 \mathrm{~g} / \mathrm{kg}$ ransum dalam ransum berbasis lumpur sawit fermentasi tidak meningkatkan konsumsi ransum tetapi meningkatkan produksi telur dan memperbaiki konversi ransum ayam ras petelur.

\section{SARAN}

Perlu dilakukan penelitian lebih lanjut terhadap proses fermentasi lumpur sawit dengan menggunakan jenis kapang atau media fermentasi yang berbeda dengan dikombinasikan dengan suplementasi ekstrak daun katuk dengan level suplementasi sebesar $6 \quad \mathrm{~g} / \mathrm{kg}$ ransum terhadap performans ayam ras petelur.

\section{DAFTAR PUSTAKA}

Akbar, Y.F. 2010. Pengaruh Lumpur Sawit Fermentasi dengan Penambahan Asam Amino Lisin, Metionin, dan Triptopan di dalam Ransum Ayam Petelur Terhadap Kualitas Telur dan Kadar Kolesterol Telur. Skripsi Jurusan Peternakan. Universitas Bengkulu, Bengkulu. 
Bintang, I.A.K, A.P. Sinurat, dan T. Purwadaria, 2003. Respon Broiler terhadap Pemberian Ransum yang Mengandung Lumpur Sawit Fermentasi pada Berbagai Lama Penyimpanan. JTIV8(2):71-75.

Darise, M. and Sulaeman. 1997. Ekstraksi komponen kimia daun katuk asal Sulawesi Selatan berbagai metode serta penelitian daya hambat terhadap bakteri uji. Warta Tumbuhan Obat, 3 (3): 37-38.

Djojosoebagio, S. 1994. Pengaruh Sauropus androgynus (L.) Merr. terhadap fungsi fisiologis dan produksi air susu. Makalah dalam Seminar Nasional Penggalian Sumber Alam Indonesia untuk Farmasi, Jakarta.

Fenita, Y., U. Santoso dan H. Prakoso. 2010. Pemanfaatan Lumpur Sawit Fermentasi dengan Neurospora $s p$ terhadap Performans Produksi dan Kualitas Telur. Jurnal Ilmu Ternak dan Veteriner. 15 (2) : 88-96.

Palinka, A. 2010. Pengaruh Asam Amino Lisin, Metionin, Triptopan dalam ransum berbasis Lumpur Sawit Fermentasi terhadap Performans Produksi dan Kualitas Telur Ayam Ras. Skripsi Jurusan Peternakan. Universitas Bengkulu, Bengkulu.

Putranto, H. D. 2011. Pengaruh Suplmentasi Daun Katuk Terhadap Ukuran Ovarium dan Oviduk Serta Tampilan Produksi Telur Ayam Burgo. JSPI Vol. 6 :103-114.

Rusfidra. 2010. Target konsumsi protein hewani Indonesia. Fakultas Peternakan UNAND, Padang.

Santoso, U dan Suharyanto. 2010. Suplementasi Ekstak Saropus androgynus untuk Meningkatkan
Efisiensi Produksi dan Mutu Telur pada Peternakan Ayam Arab Petelur. Laporan Pengabdian Masyarakat DIKTI. Jurusan Peternakan, UNIB.

Santoso, U., Y.J. Setianto, dan T.Suteky. 2005. Effect of Sauropus androgynus extract on egg production and lipid metabolism in layers. Asian-aust. J. Anim. Sci. 18: 364-369.

Santoso, U., Y. Fenita dan W. G. Wiranda. 2004. Penggunaan ekstrak daun katuk sebagai feed additive untuk memproduksi Meat Designer. Laporan Penelitian. Fakultas Pertanian, Universitas Bengkulu.

Santoso, U., J. Setianto, T. Suteky dan Y. Fenita. 2003. Suplementasi Ekstrak Daun Katuk Untuk Meningkatkan Efisiensi Produksi dan Kualitas Telur yang Ramah Lingkungan Pada Ayam Leghorn. Laporan Penelitian Bersaing Lanjutan. Lembaga Penelitian UNIB. Bengkulu.

Santoso, U., J. Setianto, T. Suteky dan Y. Fenita. 2002. Penggunaan Ekstrak Daun Katuk Untuk Meningkatkan Efisiensi Produksi dan Kualitas Telur yang Ramah Lingkungan Pada Ayam Petelur. Laporan Penelitian Hibah Bersaing Tahun 1. Universitas Bengkulu, Bengkulu, Indonesia.

Santoso, U. 2001. Effect of Sauropus androgynus Extract on Organ Weight, Toxicity and Number of Salmonella sp and Escherichia coli of Broilers Meat. B I P P, 7 (2): 162169.

Santoso, U and Sartini. 2001. Reduction of fat accumulation in broiler 
chickens by Sauropus androgynus (Katuk) leaf meal supplementation. Asian-Aust. J. Anim. Sci. 14: 346350.

Santoso, U., Suharyanto and E.Handayani. 2001. Effects of Sauropus androgynus (Katuk) leaf extract on growth, fat accumulation and fecal microorganisms in broiler chickens. J I T V, 6: 220-226.

Saparingga, Y. 2012. Suplementasi Ekstrak Daun Katuk (Sauropus androgynus) terhadap Kualitas Telur Ayam Burgo. Skripsi jurusan peternakan. Universitas Bengkulu, Bengkulu.

Sinurat, A.P 2003. Pemanfaatan Lumpur Sawit untuk Bahan Pakan Unggas. Wartoza. Buletin Ilmu Peternakan Indonesia. Vol 13 (2) 39-47.
Suprayogi, A., U. ter Meulen, T. Ungerer, and W. Manalu. 2001. Population of secretory cells and synthetic activities in mammary gland of lactating sheep after consuming Sauropus androgynus leaves. Indon. J. trop. Agric. 10 (1):1-3.

Suprayogi, A. 2000. Studies on the Biological Effets of Sauropus androgynus (L.) Merr: Effects on Milk Production and the Possibilities of Induced Pulmonary Disorder in Lactating Sheep. Cuviller Verlag Gottingen.

Yulianis, S., dan T. Marwati. 1997. Tinjauan katuk sebagai bahan makanan tambahan yang bergizi. Warta Tumbuhan Obat 3 (3): 55-56. 